\title{
A study of the elastic vertical displacement of a roadbed and HSB with an increase in speed on a high speed concrete track (HEMU-430x)
}

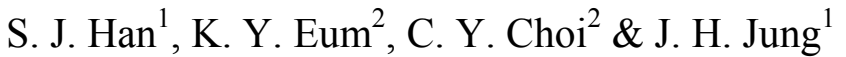 \\ ${ }^{I}$ Expert Group Earth and Environment Co., Ltd., Korea \\ ${ }^{2}$ High-Speed Railroad Infrastructure Research Team, KRRI, Korea
}

\begin{abstract}
In Korea, a speed up test of a train was performed on a high speed railway. The name of the vehicle is HEMU-430x. While the train increased speed from $300 \mathrm{~km} / \mathrm{h}$ to $421 \mathrm{~km} / \mathrm{h}$ on a railway track designed for $350 \mathrm{~km} / \mathrm{h}$, elastic vertical displacement was measured on the transition zone of bridge-earth in the Gaya overpass bridge. Until the train speed reached $421 \mathrm{~km} / \mathrm{h}$, the maximum of elastic vertical displacement measured $0.061 \mathrm{~mm}$ on top of a reinforced roadbed and $0.311 \mathrm{~mm}$ on top of a HSB (hydraulic stabilized base). Maximum vertical displacement of HSB measured at $383 \mathrm{~km} / \mathrm{h}$, displacement decreased over $383 \mathrm{~km} / \mathrm{h}$. Vertical displacement of reinforced roadbed increased according to the increase in train speed.
\end{abstract}

Keywords: roadbed, speed up test, elastic vertical displacement.

\section{Introduction}

When opening the Gyeongbu (2-phase) high-speed railway in Korea, performed the speed increase test (from $300 \mathrm{~km} / \mathrm{h}$ to $421 \mathrm{~km} / \mathrm{h}$ ) of HEMU-430X on high speed concrete track. Germany and Japan have many test results of train speed up test over $400 \mathrm{~km} / \mathrm{h}$ about trains, roadbed, concrete tracks, etc. On the other hand, speed up test was first carried out more than $400 \mathrm{~km} / \mathrm{h}$ in Korea, because a relative lack of research on the field monitoring data of track and roadbed with the speed up compared to this growth.

In Germany and Japan, developed countries in the field of railway, a variety of measurement data and database has steadily been accumulated by performed 
measurements and experiment to determine the behavioral characteristics of tracks and roadbeds during the operation of high-speed railways. However, Korea has no data measured in field to study the behavioral of the roadbed during the operation of high-speed railway at more than $350 \mathrm{~km} / \mathrm{h}$, and acquisition of international data is also not easy, the reality is that informatization of data measured in field needs to be made based on domestic proprietary technology.

In this study, data of elastic vertical displacement were obtained by measuring in a field during period of train speed up test. UIC $719 \mathrm{R}$ explains elastic vertical displacement of earth work is usually not a design criterion, because resistance of continuous supporting structure generally implies very low vertical displacement [1]. Typical range of elastic vertical displacement is 0.1 to $0.2 \mathrm{~mm}$ on top of supporting structure. Measured elastic vertical displacement in Gyeongbu (2-phase) high-speed railway give us similar result as compared to UIC $719 \mathrm{R}$ during train operation according to the test on the speed increase up to $421 \mathrm{~km} / \mathrm{h}$. Gyeongbu (2-phase) high-speed railway was built to the designed speed of $350 \mathrm{~km} / \mathrm{h}$.

In addition, data measured in field that can be utilized to study design criteria on the roadbed structures technologically available for the operation of $430 \mathrm{~km} / \mathrm{h}$ grade vehicles. Since the roadbed of the Honam high-speed railway on which trains can operate at the speed of more than $350 \mathrm{~km} / \mathrm{h}$ is under construction in 2013 , this field-test was performed to preliminary analyze the elastic behaviors of the roadbed with the speed increase up test $(300-421 \mathrm{~km} / \mathrm{h})$.

\section{Field measurement tests}

\subsection{Overview}

Field measurement location is a transition zone of bridge-earth in the Gaya overpass bridge. Gaya Overpass Bridge constructed as type of plate girder in Gyeongbu (2-phase) high-speed railway. A vehicle is HEMU-430X developed in Korea. In Speed up test, HEMU-430X speed up from $300 \mathrm{~km} / \mathrm{h}$ to $421 \mathrm{~km} / \mathrm{h}$ repeated to tuning and complement of vehicles.

Fig. 1 shows the location of measurement and drawing of sensor installation. Type of sensor is the linear variable differential transformer (LVDT). Sensors installed one each to HSB named DM-02 and Reinforced roadbed named DM01 .

Fig. 2(a) show photos of the scene in location of measuring in field. Fig. 2(b) show control box consisted of data logger, AVR (Automatic Voltage Regulator), sensor power supply, etc. fig. 3(c) show picture of sensor (DM-01) installed. Table 1 shows the location of measurement in detail.

Table 2 shows the status of sensor installation. Sensors measuring elastic vertical displacement were installed 2EA. The first sensor (DM-01) was installed on top of the roadbed and the second sensor was installed on top of HSB. Depth of displacement fixed point is GL.-3.0m. 


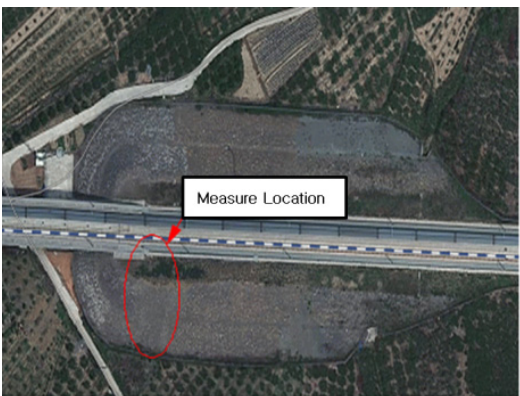

(a) Measurement location

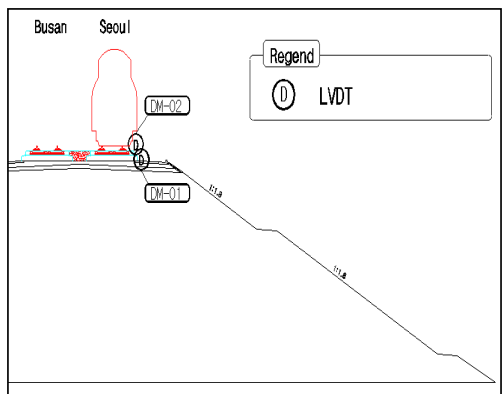

(b) Status of sensor installation.

Figure 1: Installation status of sensors.

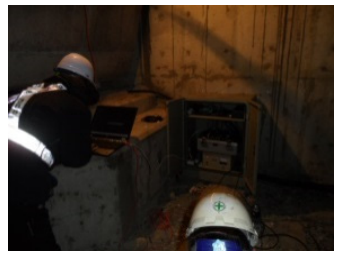

(a) Measurement in field

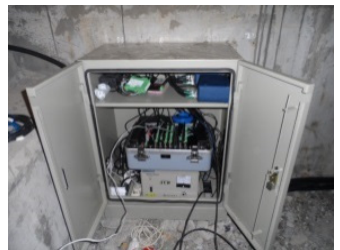

(b) Data logger

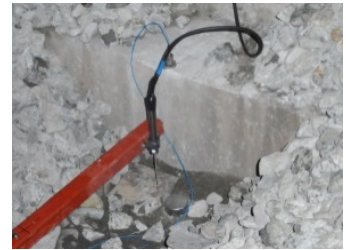

(c) Installation of DM-01

Figure 2: Installation of data logger and sensor in field.

Table 1: Measurement location details.

\begin{tabular}{|c|c|c|c|c|c|}
\hline $\begin{array}{c}\text { Name of } \\
\text { railway }\end{array}$ & $\begin{array}{c}\text { Track } \\
\text { type }\end{array}$ & $\begin{array}{c}\text { Measurement } \\
\text { location } \\
\text { description }\end{array}$ & STA & $\begin{array}{c}\text { Measure } \\
\text { ment line }\end{array}$ & Note \\
\hline $\begin{array}{c}\text { Gyeongbu } \\
(2-\text { phase) } \\
\text { high-speed } \\
\text { railway }\end{array}$ & $\begin{array}{c}\text { Concrete } \\
\text { track } \\
\text { (RHEDA } \\
\text { 2000) }\end{array}$ & $\begin{array}{c}\text { Transition zone } \\
\text { of Gaya } \\
\text { Overpass Bridge }\end{array}$ & $305 \mathrm{k} 087$ & $\begin{array}{c}\text { Up Line } \\
\text { (to Seoul) }\end{array}$ & $\begin{array}{c}\text { Train : HEMU } \\
\text { Design speed: } \\
350 \mathrm{~km} / \mathrm{h}\end{array}$ \\
\hline
\end{tabular}

Table 2: Status of sensor installation.

\begin{tabular}{|c|c|c|c|c|}
\hline Sensor name & Measure item & $\begin{array}{c}\text { Installation } \\
\text { location }\end{array}$ & Range & $\begin{array}{c}\text { Depth of } \\
\text { displacement } \\
\text { fixed point. }\end{array}$ \\
\hline DM-01 & $\begin{array}{c}\text { Elastic vertical } \\
\text { displacement }\end{array}$ & $\begin{array}{c}\text { Top of } \\
\text { Reinforced } \\
\text { Roadbed }\end{array}$ & $20 \mathrm{~mm}$ & \multirow{2}{*}{ GL. $-3 \mathrm{~m}$} \\
\cline { 1 - 3 } DM-02 & $\begin{array}{c}\text { Elastic vertical } \\
\text { displacement }\end{array}$ & Top of HSB & $20 \mathrm{~mm}$ & \\
\hline
\end{tabular}


Table 3 shows the specification of sensors and data logger. Measurement type of sensors is full bridge for measure high-speed over $1000 \mathrm{~Hz}$. Displacement range of sensor is $20 \mathrm{~mm}$. As for measuring devices, three kinds of data loggers, including DEWETRON, CR9000X and NI cRIO-9025 were used in parallel because there is no existing data carried on the roadbed behavior measurement at the train speed of more than $350 \mathrm{~km} / \mathrm{h}$ in Korea, which leads to the need to verify reliability by cross-examination on the results obtained from different sensors and measuring devices. Main data logger used CR9000X (CampbellSCI) with Trigger measurement. Other data loggers, DEWETRON and NI cRIO-9025, used for verification of measured data.

Table 3: Sensors and data logger specification.

\begin{tabular}{|c|c|c|}
\hline $\begin{array}{l}\text { Manu- } \\
\text { facturer }\end{array}$ & Model name & Details \\
\hline KYOWA & (DTH-A-20) & $\begin{array}{l}\text { Range }(\mathrm{mm}): 20 \mathrm{~mm} \\
\text { Rated Output(mV/V): } 5 \mathrm{mV} / \mathrm{V}(10000 \mu \mathrm{m} / \mathrm{m}) \\
\text { Non-Linearity }(\% \mathrm{FSO}): \pm 0.1 \\
\text { Input Resistance: } 350 \Omega \pm 0.1 \% \\
\text { Output Resistance: } 350 \Omega \pm 0.1 \% \\
\text { Operating Temperature }\left({ }^{\circ} \mathrm{C}\right):-10 \text { to } 70\end{array}$ \\
\hline $\begin{array}{c}\text { Campbell } \\
\text { SCI }\end{array}$ & $(\mathrm{CR} 9000 \mathrm{X})$ & $\begin{array}{l}\text { Maximum Scan Rate: } 100,000 \mathrm{~Hz} \\
\text { Analog Voltage Accuracy: } \pm(0.07 \% \text { of }) \\
\text { Analog Resolution: to } 1.6 \mu \mathrm{V} \\
\text { A/D Bits: } 16 \\
\text { Temperature Range: }-25^{\circ} \text { to }+50^{\circ} \mathrm{C} \\
\text { Memory : } 128 \mathrm{MB}-2 \mathrm{~GB}\end{array}$ \\
\hline
\end{tabular}

\subsection{Test conditions}

Table 4 shows speeds of vehicle from $300 \mathrm{~km} / \mathrm{h}$ to $421 \mathrm{~km} / \mathrm{h}$ order by date [2]. Approximately $10 \mathrm{~km} / \mathrm{h}$ speed up per week. HEMU-430X traveling to same speed 1-3 times at midnight. When vehicle is passing the measurement location, data logger saved elastic vertical displacement about roadbed and HSB during 10 seconds. The Sampling rate was determined to be $2.5 \mathrm{kHz}$ for prevented to miss a maximum of displacement. After train has passed, measured data is automatically sent to remote measure server through 3GPP Long Term Evolution (LTE) wireless modem.

\section{Analysis of test results}

The representative elastic vertical displacement of reinforced roadbed and HSB measurement values by HEMU-430x were presented in Figs. 3-6. The vertical displacement was measured by increasing the speed of the train by $10 \mathrm{~km} / \mathrm{h}$ from $300 \mathrm{~km} / \mathrm{h}$ to $421 \mathrm{~km} / \mathrm{h}$. 
Table 4: Schedule of speed up test.

\begin{tabular}{|c|c|c|c|c|c|c|c|}
\hline Phase & Test date & $\begin{array}{l}\text { Speed } \\
(\mathrm{km} / \mathrm{h})\end{array}$ & $\begin{array}{c}\text { No. of } \\
\text { speed test }\end{array}$ & Phase & Test date & $\begin{array}{l}\text { Speed } \\
(\mathrm{km} / \mathrm{h})\end{array}$ & $\begin{array}{c}\text { No. of } \\
\text { speed test }\end{array}$ \\
\hline \multirow{6}{*}{$\begin{array}{c}1 \text { st } \\
\text { speed } \\
\text { up test }\end{array}$} & '12.7.15 & 300 & 3 times & \multirow{12}{*}{$-\begin{array}{c}2 \text { nd } \\
\text { speed }\end{array}$} & '12.12.23 & 396 & 3 times \\
\hline & '12.8.12 & 312 & 3 times & & '12.12.27 & 394 & 2 times \\
\hline & '12.8.16 & 321 & 3 times & & ' 12.12 .30 & 394 & 1 time \\
\hline & '12.8.23 & 334 & 3 times & & '13.01.17 & 370 & 2 times \\
\hline & '12.9.01 & 342 & 3 times & & '13.01.20 & 396 & 2 times \\
\hline & '12.9.08 & 342 & 3 times & & '13.01.27 & 400 & 2 times \\
\hline \multirow{6}{*}{$\begin{array}{c}2 \text { nd } \\
\text { speed } \\
\text { up test }\end{array}$} & '12.11.29 & 351 & 1 time & & '13.02.03 & 400 & 2 times \\
\hline & '12.12.02 & 354 & 2 times & & '13.02.24 & 413 & 2 times \\
\hline & '12.12.09 & 355 & 2 times & & '13.02.28 & 412 & 2 times \\
\hline & ' 12.12 .13 & 378 & 3 times & & '13.03.03 & 400 & 1 time \\
\hline & '12.12.16 & 383 & 3 times & & '13.03.28 & 421 & 2 times \\
\hline & ' 12.12 .20 & 386 & 3 times & & ' 13.03 .31 & 420 & 2 times \\
\hline
\end{tabular}

Fig. 3 show displacement of on top reinforced roadbed (DM-01) at 300km/h. Vertical displacement of DM-01 hasn't detected because of raw data measured within the resolution of the sensor. On the other hand, DM-2 (installed on top of HSB) measured $0.05 \mathrm{~mm}$ very small (fig. 4).

Fig. 5 show displacement of on top reinforced roadbed (DM-01) at $431 \mathrm{~km} / \mathrm{h}$. Vertical displacement of DM-01 measured $0.05 \mathrm{~mm}$ and DM-2 measured $0.22 \mathrm{~mm}$ (fig. 6).

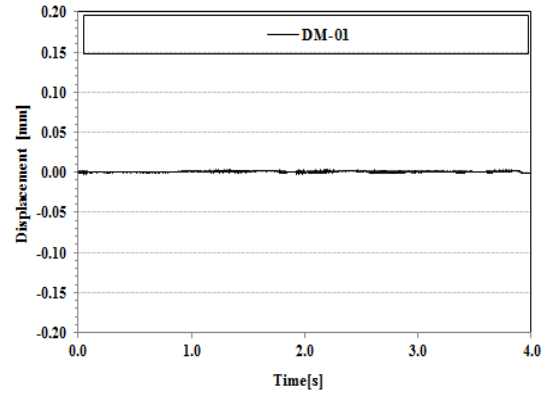

(a) Time Series of DM-01

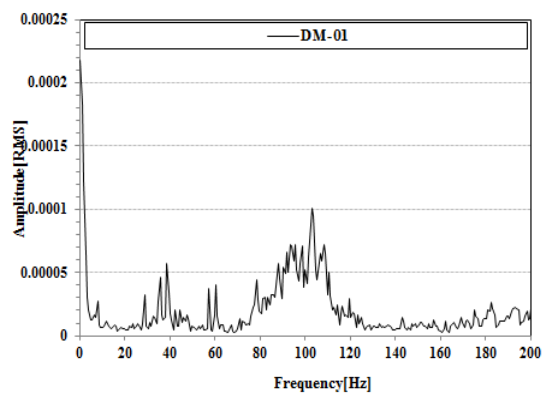

(b) FFT of DM-01

Figure 3: Elastic vertical displacement of DM-01 at 306 km $/ \mathrm{h}$ (HEMU-430X). 


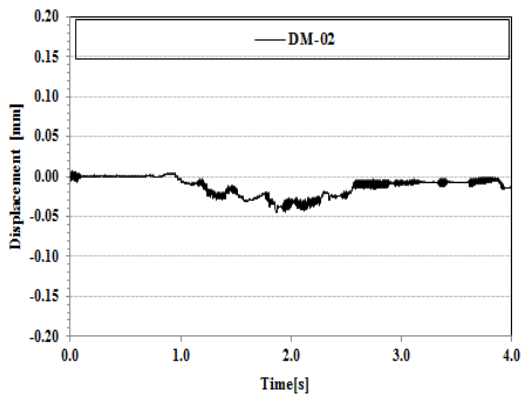

(a) Time Series of DM-02

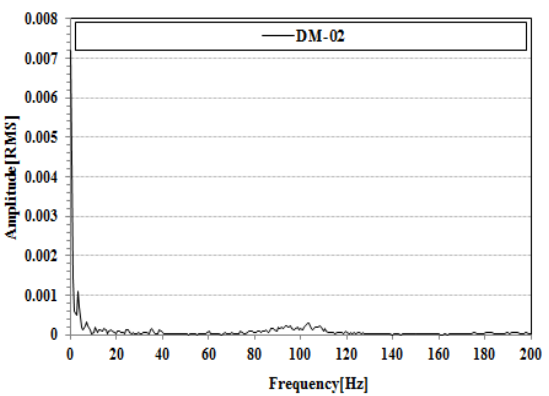

(b) FFT of DM-02

Figure 4: Elastic vertical displacement of DM-02 at 306km/h (HEMU-430X).

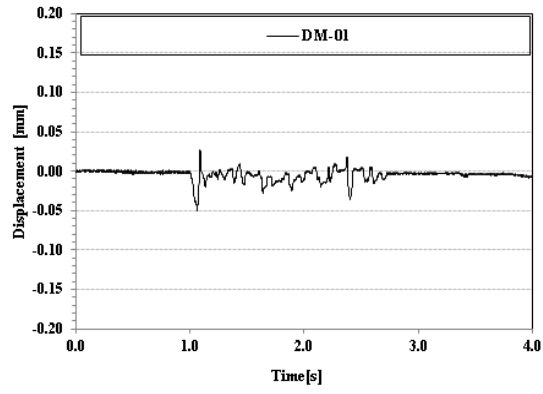

(a) Time Series of DM-01

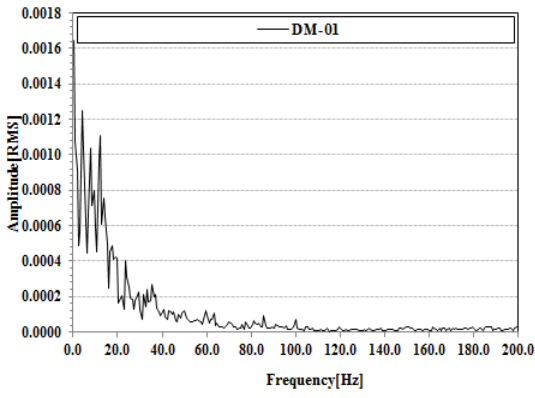

(b) FFT of DM-01

Figure 5: Elastic vertical displacement of DM-01 at $421 \mathrm{~km} / \mathrm{h}$ (HEMU-430X).

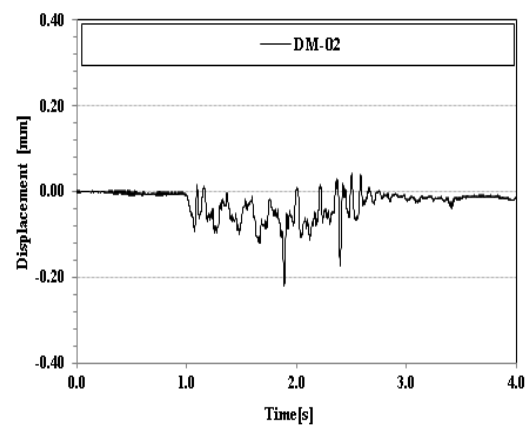

(a) Time Series of DM-01

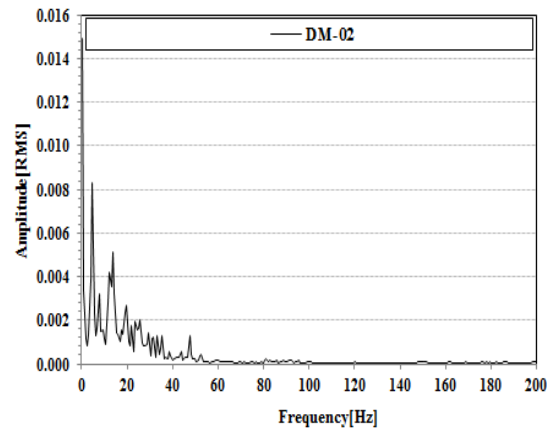

(b) FFT of DM-02

Figure 6: Elastic vertical displacement of DM-01 at $421 \mathrm{~km} / \mathrm{h}$ (HEMU-430X). 


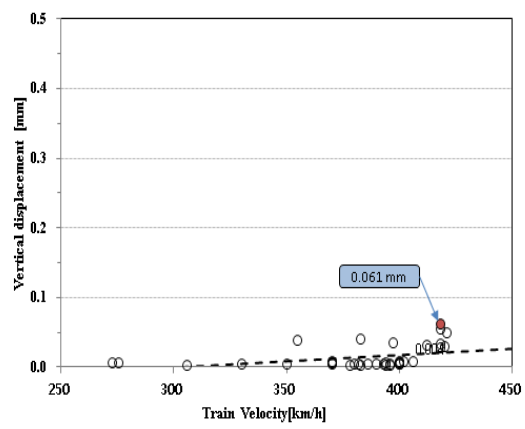

(a) Time Series of DM-01

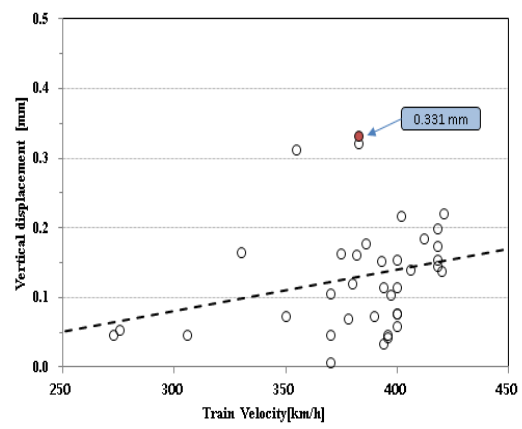

(b) Time Series of DM-02

Figure 7: Elastic vertical displacement of DM-01 at 306 km $/ \mathrm{h}$ (HEMU-430X).

Fig. 7 shows a schematic diagram that displays measurement values of the reinforced roadbed and HSB compared to standard values during speed increase test of HEMU-430X. Until the train speed reach to $421 \mathrm{~km} / \mathrm{h}$, maximum of elastic vertical displacement measured $0.061 \mathrm{~mm}$ on top of reinforced roadbed and $0.311 \mathrm{~mm}$ on top of HSB (Hydraulic Stabilized Base). Maximum vertical displacement of HSB measured at $383 \mathrm{~km} / \mathrm{h}$ and displacement decreased over $383 \mathrm{~km} / \mathrm{h}$. Vertical displacement of reinforced roadbed is increased according to increase train speed.

As shown in Table 5, elastic vertical displacement was measured at less than $2.4 \%$ compare to design criterion in the roadbed [3], but it was $33 \%$ compared to the criterion in HSB of the concrete track. Accordingly, the results of performance evaluation on the elastic displacement of the roadbed and HSB in the transition zone of Gaya Overpass with HEMU-430X as targets were all evaluated to be behaviors within the range of design criterion.

Table 5: Elastic vertical displacement performance evaluation.

\begin{tabular}{|c|c|c|c|c|}
\hline $\begin{array}{c}\text { Measurement } \\
\text { location }\end{array}$ & $\begin{array}{c}\text { Design } \\
\text { criterion }\end{array}$ & $\begin{array}{c}\text { Maximum } \\
\text { measurement } \\
\text { value (train } \\
\text { speed) }\end{array}$ & Evaluation & Remarks \\
\hline Reinforced roadbed & $2.5 \mathrm{~mm}$ & $\begin{array}{c}0.061 \mathrm{~mm} \\
(418 \mathrm{~km} / \mathrm{h})\end{array}$ & $\begin{array}{c}\text { Within } \\
\text { criterion } \\
(2.4 \%)\end{array}$ & $\begin{array}{c}\text { Maximum } \\
\text { value of LPF } \\
300 \mathrm{~Hz}\end{array}$ \\
\hline $\begin{array}{c}\text { HSB (hydraulic } \\
\text { stabilized base) }\end{array}$ & $1 \mathrm{~mm}$ & $\begin{array}{c}0.331 \mathrm{~mm} \\
(383 \mathrm{~km} / \mathrm{h})\end{array}$ & $\begin{array}{c}\text { Within } \\
\text { criterion } \\
(33 \%)\end{array}$ & $\begin{array}{c}\text { Maximum } \\
\text { value of LPF } \\
300 \mathrm{~Hz}\end{array}$ \\
\hline
\end{tabular}




\section{Conclusion}

During the increase in train speed from $300 \mathrm{~km} / \mathrm{h}$ to $421 \mathrm{~km} / \mathrm{h}$ on a railway line designed for $350 \mathrm{~km} / \mathrm{h}$ in Gyeongbu (2-phase) high-speed railway, elastic vertical displacement was measured at less than $2.4 \%$ compared to design criterion $(2.5 \mathrm{~mm})$ in the reinforced roadbed and at less than $33 \%$ compared to the criterion $(1 \mathrm{~mm})$ on top of HSB in the transition zone of Gaya Overpass with HEMU$430 \mathrm{X}$. The results of performance evaluation on the elastic displacement of the roadbed and HSB in the transition zone of Gaya Overpass with HEMU-430X as targets were all evaluated to be behaviors within the range of design criterion.

\section{Acknowledgement}

This work is financially supported by Ministry of Land, Transport and Maritime Affairs (MLTM) through a research project "Development of Infra Technology for $400 \mathrm{~km} / \mathrm{h}$ High Speed Rail”.

\section{References}

[1] International Union of Railways (2008). “(UIC 719 R) Earthworks and track bed for railway lines."

[2] Korea Rail Network Authority (2010). "Services of testing verification of facility from Daegu to Busan in Gyoungbu high speed railroad."

[3] Japan Railway Track Consultants (2009). "Performance criteria and case studies of the orbit system in Japan." 